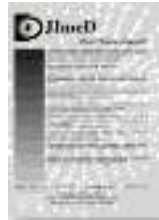

Jurnal Imejing Diagnostik (JImeD) 6 (2020) 36-48

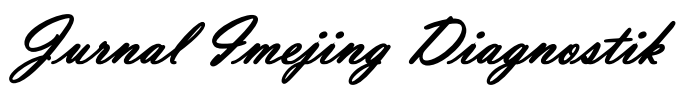

e-ISSN 2621-7457, p-ISSN 2356-301X

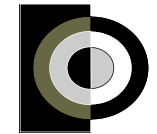

http://ejournal.poltekkessmg.ac.id/ojs/index.php/jimed/index

\title{
Perbedaan Informasi Citra Anatomi sekuen Diffusion Weighted Imaging (DWI) antara Penggunaan Propeller dengan tanpa Propeller pada Pemeriksaan MRI BRAIN dengan Kasus Store
}

\author{
Yeti Kartikasari ${ }^{1}$, M. Irwan Katili ${ }^{2}$, Dwi Rochmayanti ${ }^{3}$, Nindya Aprilia ${ }^{4}$ \\ ${ }^{1,2,3)}$ Jurusan Teknik Radiodiagnostik dan Radioterapi, Poltekkes Kemenkes Semarang, Indonesia \\ 4) Rumah Sakit Moewardi, Solo, Indonesia \\ Corresponding author: Yeti Kartikasari \\ e-mail: yeti.kartikasari@gmail.com
}

Received: January $30^{\text {th }}, 2020$; Revised: January $31^{\text {th }}, 2020$; Accepted: January $31^{\text {th }}, 2020$

\begin{abstract}
Background: Stroke is a brain disease where an acute nerve function is occurred due to the cerebral vascular disorders. To establish a diagnosis the stroke, it can be identified by employing the Diffusion Weighted Imaging (DWI) sequence in the MRI examination. Artifacts still exist on the MRI image which in turn reduce the resolution when using the DWI sequence. Adding the PROPELLER data acquisition method in the DWI sequence possibly improves the quality of brain images. The purpose of this study is to know the difference on the quality of anatomical image information between the DWI sequences with PROPELLER and without PROPELLER methods, and to determine adequate anatomical image appearance that created in amongst of the two methods, specifically for the stroke disease.

Methods: this research is quantitative research with experimental approach. This study was conducted using MRI 1.5 T at Bethesda Hospital Yogyakarta. Data were 16 images from 8 patients using DWI sequences using PROPELLER without PROPELLER on MRI Brain examination with stroke. The results of the image were evaluated on 7 criteria: cortex cerebri, basal ganglia, thalamus, pons, cerebellum, stroke (infarction) and artifacts using questionnaires given to 3 respondents. Data analysis was done by Wilcoxon test to know the difference of anatomical image information on DWI sequence using PROPELLER without PROPELLER and to know better anatomical image information from both sequences seen from mean rank value.

Results: The results shown, there is a significant difference on the quality of anatomical image information and the artifacts between the use of DWI sequence with and without PROPELLER methods $(<0.05)$. Based on the mean rank results, the DWI PROPELLER sequence has a higher mean rank value 4.50 compared to the DWI sequence without PROPELLER 0.00.

Conclusions: The DWI PROPELLER sequence has better image results compared to the DWI sequence without PROPELLER.
\end{abstract}

Keyword: MRI Brain; Stroke; PROPELLER; DWI.

\section{Pendahuluan}

Stroke adalah gangguan fungsi saraf akut yang disebabkan karena gangguan peredaran darah otak yang disertai dengan timbulnya gejala dan tanda yang sesuai dengan daerah fokal pada otak yang terganggu, baik yang terjadi secara mendadak (dalam beberapa detik) atau secara cepat (dalam beberapa jam) (Noerjanto M., 2002). Stroke dibedakan menjadi dua, yaitu stroke hemoragik dan stroke iskemik (Victor, M., 2001).

Menurut Neseth (2010) untuk mendapatkan informasi yang akurat pemeriksaan MRI Brain dibuat tiga potongan yakni potongan aksial, sagital dan koronal. Parameter sekuens yang dipakai dalam pemeriksaan MRI Brain menurut Fisher (2001) adalah T1 WI, T2 WI, Proton Density/ FLAIR sebagai basic sekuens dan diikuti Difussion 
Weighted Imaging (DWI), PWI (Perfusion Weighted Imaging) serta MRA (Magnetic Resonance Angiography).

Sekuen DWI adalah sekuen yang memanfaatkan gerakan atau movement dari molekul-molekul akibat adanya gerak thermal yang acak. Gerakan ini dibatasi oleh batas-batas seperti ligamen, membran dan makromolekul. Sekuen DWI menunjukan area dengan difusi terbatas pada air ekstraselular seperti jaringan infark. Pada jaringan normal, air ekstraselular berdifusi secara acak sedangkan pada jaringan iskemik, sel-sel membengkak dan menyerap air dari ruang ekstraselular (Westbrook, 2014)

PROPELLER adalah sebuah metode dari akuisisi data untuk mengurangi artefak yang merupakan metode baru dalam proses pengumpulan dan rekonstruksi data yang diakibatkan oleh rotasi dan pergerakan obyek (Pipe, 1999). Metode PROPELLER adalah untuk mengisi $\mathrm{k}$ space dengan cara berputar dengan satu set strip (bilah) yang diarahkan secara radial dengan oversampling yang dihasilkan pada pusat $\mathrm{k}$ space. PROPELLER dapat diaplikasikan pada sekuen DWI, Fluid Attenuated Inversion Recovery (FLAIR), T2 Weighted Image (Elster, 2017).

$\mathrm{K}$ space merupakan domain yang mempunyai sumbu yang saling tegak lurus yang berisi frekuensi data fase sinyal yang berasal dari tubuh pasien yang merupakan tempat informasi mengenai frekuensi dan fase disimpan. Pada sekuen DWI pengisian $\mathrm{k}$ space dilakukan secara rectilinear yang memperoleh data line by line. Sedangkan pada sekuen DWI PROPELLER pengisian k space secara radial oleh multiple blade yang berotasi 360 pada pusat $\mathrm{k}$ space yang disampling berulang kali dan setiap blade berisi phase encoding lines yang dapat meminimalisir phase eror motion.

Hasil penelitian Omar Mahmuda, dkk (2010) menyebutkan bahwa penggunaan PROPELLER pada DWI dapat mengurangi artefak dan sangat berguna dalam pemeriksaan sellar dan parasellar. Attenberger, dkk. (2009) menyebutkan bahwa penggunaan PROPELLER pada DWI pada pemeriksaan MRI Brain lebih baik dalam meningkatkan kualitas citra dan mengurangi adanya artefak.

Sekuen yang digunakan pada Rumah Sakit Bethesda Yogyakarta dalam pemeriksaan MRI Brain dengan kasus Stroke yaitu dengan menggunakan pesawat MRI GE Signa 1,5 T yaitu Ax T2 PROPELLER, AX T2 FLAIR, AX T1 FSE, AX T2* GRE, SAG T1, COR T2 FSE, AX DWI. Penggunaan sekuen DWI digunakan untuk memperlihatkan lesi-lesi iskemik dan memperkirakan jaringan yang masih bisa diselamatkan sebelum dilakukan intervensi terapi. Tetapi pada penggunaan sekuen DWI banyak dijumpai adanya bayangan putih (artefak) yang mengganggu kualitas citra pada pemeriksaan MRI Brain. Gambaran Stroke pada citra DWI adalah hiperintens (terang) sementara gambaran artefak yang biasa dijumpai pada citra DWI juga terlihat hiperintens (terang) sehingga hal demikian dapat mengganggu dokter Radiologi dalam menilai dan mendiagnosa gambaran MRI pada pasien stroke.

Pemeriksaan MRI Brain khususnya pada pasien stroke di Rumah Sakit Bethesda Yogyakarta tidak menggunakan sekuen DWI dengan PROPELLER. Berdasarkan teori dengan penggunaan PROPELLER dapat mengurangi artefak dan meningkatkan kualitas citra. Berdasarkan latar belakang tersebut peneliti tertarik untuk melakukan penelitian dengan tujuan untuk mengetahui perbedaan informasi anatomi sekuen Diffusion Weighted Imaging (DWI) antara penggunaan PROPELLER dengan tanpa PROPELLER pada pemeriksaan MRI Brain dengan kasus stroke dan mengetahui informasi citra anatomi yang lebih baik dihasilkan pada sekuen DWI antara penggunaan PROPELLER dengan tanpa PROPELLER pada pemeriksan MRI Brain dengan kasus stroke.

\section{Methods (Metode)}

Populasi dalam penelitian ini adalah semua pemeriksaan MRI Brain dengan kasus stroke di Instalasi Radiologi Rumah Sakit Bethesda Yogyakarta. Adapun penentuan sample menggunakan rumus besaran sample menggunakan metode Lameshow (Notoatmodjo, 2002).

Dengan demikian sample penelitian ini adalah 8 orang pasien yang melakukan pemeriksaan MRI Brain dengan stroke mengunakan sekuen DWI dengan penggunaan PROPELLER dengan tanpa PROPELLER.

Prosedur pembuatan citra sebagaimana Prosedur Pemeriksaan MRI Brain kasus Stroke di Instalasi Radiologi Rumah Sakit Bethesda Yogyakarta

a. Memberikan penjelasan kepada pasien tentang pemeriksaan yang akan dilakukan termasuk lamanya waktu pemeriksaan.

b. Melepaskan semua barang yeng bersifat feromagnetik dan bila perlu mengganti pakaian dengan pakaian khusus yang disediakan

c. Memasukkan data pasien ke komputer dan memilih sekuen yang digunakan. 
d. Menyiapkan head coil

a. Pasien diposisikan supine diatas meja pemeriksaan dengan kepala didalam head coil.

b. Atur kepala agar interpupilari line paralel dengan meja pemeriksaan dan pastikan kepala lurus.

c. Pasien diposisikan dengan sinar garis longitudinal berada pada MSP dan sinar garis horisontal setinggi nassion.

d. Strap dan pengganjal dapat digunakan sebagai imobilisasi bila diperlukan.

e. Setelah setelah memposisikan pasien selesai pintu ditutup rapat agar tidak ada interferensi dari luar.

f. Melakukan pemeriksaan dengan pesawat MRI 1,5 $\mathrm{T}$ dengan parameter terkontrol FOV, Slice Thickness, TR, TE, B value, Bandwidth

g. Pemeriksaan dilakukan dengan sekuen DWI dan sekuen DWI PROPELLER yang dilakukan pada obyek kepala kepada 8 pasien, dengan cara masing-masing pasien dilakukan scanning dengan sekuen DWI kemudian dilanjutkan dengan scanning sekuen DWI PROPELLER.

h. Pada masing-masing sekuen dilakukan pengaturan parameter yang sama sehingga teknik scanning dan parameter tetap terkontrol.

i. Setelah hasil citra diperoleh tahap selanjutnya adalah melakukan printing pada masing-masing citra.

Prosedur Penilaian Citra dilakukan oleh tiga dokter spesialis radiologi diminta untuk mencermati citra MRI Brain kasus Stroke yang telah dicetak dalam film dengan tidak disertakan keterangan apapun baik identitas pasien maupun parameter yang digunakan dan hanya diberi kode seri citra.

Penilaian dokter spesialis radiologi untuk informasi citra dilakukan dengan memberikan tanda cek (v) pada kuisioner yang disediakan sesuai dengan petunjuk. Kuisioner berisi penilaian terhadap informasi citra anatomi. Kemudian hasil kuesioner berupa angka yang akan diolah menggunakan aplikasi SPSS. Penilaian skor 1 "kurang jelas" bila objek yang dinilai mempunyai batas yang tidak tegas, kabur dan sulit diamati, skor 2 "cukup jelas" bila objek yang dinilai tampak jelas, namun tidak berbatas tegas, skor 3 "jelas" bila batas tepi antar objek yang dinilai tampak jelas, mempunyai batas yang tegas, dan mudah diamati. Sementara untuk penilaian skor artefak pada gambaran yaitu skor 1 "banyak terlihat artefak", skor 2 "sedikit terlihat artefak", skor 3 "tidak terlihat artefak".

Data hasil kuisoner yang diperoleh dari hasil ekspertisi 3 dokter spesialis Radiologi terhadap 16 citra pada sekuen DWI dan DWI PROPELLER pada pemeriksaan MRI Brain. Data yang dihasilkan berupa data ordinal dari hasil jawaban kuisoner yang diberikan dokter spesialis radiologi mengenai kejelasan informasi anatomi dan keberadaan artefak.

Data hasil jawaban kuisioner oleh observer (dokter spesialis radiologi) yang diperoleh dari hasil perbandingan sekuen Diffusion Weighted Image (DWI) antara penggunaan PROPELLER dengan tanpa PROPELLER pada MRI Brain dengan kasus stroke adalah ordinal. data dianalisa dengan Uji Wilcoxon untuk mengetahui perbedaan informasi citra anatomi antara kedua teknik tersebut, penilaian didasarkan pada teori sugiyono (2004), jika p-value lebih kecil atau sama dengan 0,05 maka Ha diterima dan Ho ditolak, dan untuk informasi citra anatomi manakah yang lebih baik antara kedua teknik tersebut penilaian didasarkan dengan melihat Mean Ranks.

\section{Hasil dan Pembahasan}

\section{a. Deskipsi Karakteristik Sample}

Tabel 1. Deskripsi Sample Berdasarkan Jenis Kelamin

\begin{tabular}{ccc}
\hline $\begin{array}{c}\text { Jenis } \\
\text { Kelamin }\end{array}$ & Jumlah & $\begin{array}{c}\text { Prosentase } \\
(\%)\end{array}$ \\
\hline Laki-laki & 5 & $62.5 \%$ \\
Perempuan & 3 & $37.5 \%$ \\
\hline Total & 8 & $100 \%$ \\
\hline
\end{tabular}

Berdasarkan tabel tersebut diketahui penelitian ini menggunakan 8 pasien stroke dengan prosentase laki-laki sebesar $62.5 \%$ dan perempuan sebesar $37.5 \%$

Tabel 2. Deskripsi Sample Berdasarkan Umur

\begin{tabular}{ccc}
\hline Umur & Jumlah & Prosentase $(\%)$ \\
\hline 40-50 tahun & 3 & $37.5 \%$ \\
$51-60$ tahun & 5 & $62.5 \%$ \\
\hline Total & 8 & $100 \%$ \\
\hline
\end{tabular}

Berdasarkan tabel tersebut, penelitian ini menggunakan pasien stroke seumlah 8 orang dengan rentang umur 40-60 tahun sebanyak 37.5\% dan 51-60 sebanyak $62.5 \%$.

Tabel 3. Karakteristik Responden 


\begin{tabular}{ccc}
\hline Responden & $\begin{array}{c}\text { Lama } \\
\text { Bekerja }\end{array}$ & Jabatan \\
\hline 1 & 5 tahun & $\begin{array}{c}\text { Dokter Spesialis } \\
\text { Radiologi } \\
\text { Dokter Spesialis } \\
\text { Radiologi }\end{array}$ \\
3 & 17 tahun & $\begin{array}{c}\text { Dokter Spesialis } \\
\text { Radiologi }\end{array}$ \\
\hline
\end{tabular}

Responden mengisi kuisoner dengan menggunakan check list dengan kriteria yang dinilai pada 7 kriteria yaitu cortex cerebri, basal ganglia, thalamus, pons, cerebellum, kelainan stroke dalam hal ini melihat infark dan penilaian terhadap artefak. Sehingga masing-masing radiolog atau responden memberikan penilaian terhadap citra MRI Brain pada sekuen DWI dengan dan tanpa PROPELLER pada kasus stroke sebanyak 16 citra yang terdiri dari 8 citra DWI tanpa PROPELLER dan 8 citra DWI dengan PROPELLER.

Gambar 1. Citra Anatomi yang akan Responden

(a)Cortex cerebri, (b) Kelainan stroke (infark), (c)

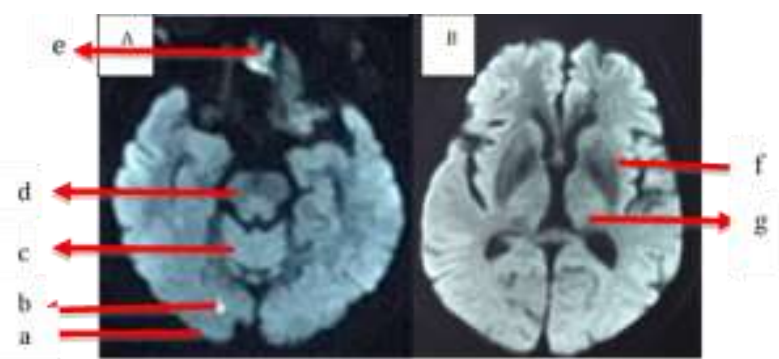

Cerebellum, (d) Pons, (e) Artefak, (f) Basal ganglia, (g) thalamus

\section{Perbedaan Informasi Citra Anatomi Sekuen Diffusion Weighted Imaging (DWI) antara penggunaan PROPELLER dengan tanpa PROPELLER pada pemeriksaan MRI Brain dengan kasus stroke.}

Hasil dari penelitian dilakukan Uji Statistik dengan menggunakan SPSS 23 yaitu uji Cohen's Kappa untuk mengetahui kesesuaian antar responden yaitu responden 1 dengan responden 2, responden 1 dengan responden 3 , dan responden 2 dengan responden 3 .

Hasil kuisioner dari ketiga responden kemudian di analisa dengan menggunakan uji Cohen's Kappa untuk mengetahui tingkat kesepakan dari objektifitas dari ketiga responden terhadap penelitian. Uji Cohen's Kappa diuji pada setiap variasi. Adapun hasil uji statistik Cohen's Kappa adalah sebagai berikut :
Tabel 4. Hasil Nilai Pengujian Cohen's Kappa Terhadap Informasi Citra Anatomi

\begin{tabular}{|c|c|c|c|c|c|}
\hline \multirow{3}{*}{$\begin{array}{l}\text { Sekuen } \\
\text { DWI } \\
\text { dengan dan } \\
\text { tanpa } \\
\text { PROPELL } \\
\text { ER }\end{array}$} & \multicolumn{3}{|c|}{$\begin{array}{c}\text { Tingkat } \\
\text { kesepakatan } \\
\text { Cohen's Kappa }\end{array}$} & \multirow[t]{3}{*}{$\begin{array}{l}\text { Rata- } \\
\text { rata }\end{array}$} & \multirow[t]{3}{*}{$\begin{array}{l}\text { Ketera- } \\
\text { ngan }\end{array}$} \\
\hline & $\mathrm{R} 1 *$ & $\mathrm{R} 1 *$ & $\mathrm{R} 2 *$ & & \\
\hline & R2 & R3 & R3 & & \\
\hline & $\begin{array}{l}0.98 \\
0\end{array}$ & $\begin{array}{l}0.9 \\
80\end{array}$ & $\begin{array}{l}1.0 \\
0\end{array}$ & 0.986 & $\begin{array}{l}\text { Sangat } \\
\text { Baik }\end{array}$ \\
\hline
\end{tabular}

Berdasarkan tabel 4, dapat dilihat nilai kesepakatan antar ketiga reponden berada dalam tingkat kesepakatan yang sangat baik (Altman, 1991) yaitu dalam rentang 0,81 - 1,00 dimana nilai rata-rata pengujian sekuen DWI dengan dan tanpa PROPELLER adalah 0.986 .

Tabel 5. Hasil Nilai Pengujian Cohen's Kappa Terhadap Informasi Citra Artefak

\begin{tabular}{llllll}
\hline $\begin{array}{l}\text { Sekuen } \\
\text { DWI dengan } \\
\text { dan tanpa }\end{array}$ & \multicolumn{3}{c}{$\begin{array}{c}\text { Tingkat } \\
\text { kesepakatan } \\
\text { Cohen's Kappa }\end{array}$} & $\begin{array}{l}\text { Rata } \\
\text {-rata }\end{array}$ & $\begin{array}{l}\text { Ketera } \\
\text { ngan }\end{array}$ \\
\cline { 2 - 6 } & $\mathrm{R}^{*}$ & $\mathrm{R} 1 *$ & $\mathrm{R} 2 *$ & & \\
& $\mathrm{R} 2$ & $\mathrm{R} 3$ & $\mathrm{R} 3$ & & \\
\hline & 0.81 & 0.81 & 0.81 & 0.81 & Sangat \\
& 1 & 0 & 1 & 0 & Baik \\
\hline
\end{tabular}

Setelah dilakukan uji Cohen's Kappa, maka dipilih responden untuk dilakukan uji Wilcoxon. Pemilihan responden ini didasarkan pada nilai kesepakatan yang baik dan lamanya responden bekerja yaitu responden 3 dengan lama bekerja 21 tahun. Selanjutnya dilakukan uji Wilcoxon, karena data yang didapat berupa ordinal, data yang digunakan kurang dari 30 dan berasal dari 2 data sampel berpasangan untuk mengetahui perbedaan informasi citra anatomi antara kedua teknik tersebut.Pengujian perbedaan informasi citra anatomi antara menggunakan PROPELLER dan tanpa menggunakan PROPELLER sebagai berikut :

Tabel 6. Hasil Uji Wilcoxon Perbedaan Informasi Anatomi secara keseluruhan

\begin{tabular}{lll}
\hline Sekuen & p-value & Keterangan \\
\hline DWI & 0.000 & Ada beda \\
PROPELLER dan & & \\
DWI Tanpa & & \\
PROPELLER & & \\
\hline
\end{tabular}

Berdasarkan tabel hasil Uji wilcoxon dengan tingkat kepercayaan (confidence level) $95 \%$. Menunjukan nilai signifikansi $\rho<0,05$ pada seluruh organ yaitu pada Cortex Cerebri, Basal Ganglia, Thalamus, Pons, Cerebellum dan Kelainan Stroke 
(Infark) artinya Ho ditolak dan Ha diterima. Hal tersebut menujukan adanya perbedaan yang bermakna pada sekuen DWI antara penggunaan PROPELLER dengan tanpa PROPELLER.

Tabel 7. Hasil Uji Wilcoxon Informasi Anatomi Setiap Bagian Pada Sekuen DWI antara penggunaan PROPELLER dengan tanpa PROPELLER

\begin{tabular}{lcc}
\hline Organ & $\begin{array}{l}\boldsymbol{p} \text { - } \\
\text { value }\end{array}$ & Keterangan \\
\hline Cortex Cerebri & 0.005 & Ada beda \\
\hline Basal Ganglia & 0.007 & Ada beda \\
\hline Thalamus & 0.005 & Ada beda \\
\hline \multicolumn{1}{c}{ Pons } & 0.005 & Ada beda \\
\hline Cerebellum & 0.008 & Ada beda \\
\hline $\begin{array}{l}\text { Kelainan Stroke } \\
\text { (batas) }\end{array}$ & 0.005 & Ada beda \\
\hline
\end{tabular}

Berdasarkan tabel hasil Uji Wilcoxon informasi anatomi pada organ anatomi Cortex Cerebri adalah 0,005, Basal Gangliat adalah 0,007, Thalamus adalah 0,005, Pons adalah 0,005, Cerebellum adalah 0,008 dan Kelainan Stroke (infark) adalah 0,005 diperoleh $\rho<0,05$ dengan tingkat kepercayaan (confidence level) $95 \%$, artinya Ho ditolak dan Ha diterima, hal ini menunjukan adanya perbedaan yang bermakna pada sekuen DWI antara penggunaan PROPELLER dengan tanpa PROPELLER.

Tabel 8. Hasil Uji Wilcoxon Informasi Artefak pada Sekuen DWI antara penggunaan PROPELLER dengan tanpa PROPELLER

\begin{tabular}{lcc}
\hline \multicolumn{1}{c}{ SEKUEN } & $\boldsymbol{\rho}$-value & Arti \\
\hline DWI TANPA & & \\
PROPELLER & 0,009 & Ada Beda \\
\cline { 1 - 1 } DWI PROPELLER & & \\
\hline
\end{tabular}

Berdasarkan tabel hasil uji Wilcoxon didapat nilai mean rank untuk masing-masing organ terhadap sekuen DWI pada penggunaan PROPELLER dengan tanpa PROPELLER di dapatkan hasil bahwa pada cortex cerebri, basal ganglia, thalamus, pons, cerebellum, kelainan stroke (batas) dan artefak memiliki nilai mean rank sebesar 4.50 pada sekuen DWI PROPELLER dan nilai mean rank sebesar 0 pada sekuen DWI tanpa PROPELLER.
Tabel 9. Hasil Mean Rank Uji Wilcoxon pada keseluruhan organ

\begin{tabular}{|c|c|c|}
\hline \\
\hline Anatomi Citra & Sekuen & $\begin{array}{l}\text { Mean } \\
\text { Rank }\end{array}$ \\
\hline \multirow[t]{2}{*}{ Cortex Cerebri } & $\begin{array}{l}\text { DWI Tanpa } \\
\text { PROPELLER }\end{array}$ & 0 \\
\hline & DWI PROPELLER & 4.50 \\
\hline \multirow[t]{2}{*}{ Basal Ganglia } & $\begin{array}{l}\text { DWI Tanpa } \\
\text { PROPELLER }\end{array}$ & 0 \\
\hline & DWI PROPELLER & 4.50 \\
\hline \multirow[t]{2}{*}{ Thalamus } & $\begin{array}{l}\text { DWI Tanpa } \\
\text { PROPELLER }\end{array}$ & 0 \\
\hline & DWI PROPELLER & 4.50 \\
\hline \multirow[t]{2}{*}{ Pons } & $\begin{array}{l}\text { DWI Tanpa } \\
\text { PROPELLER }\end{array}$ & 0 \\
\hline & DWI PROPELLER & 4.50 \\
\hline \multirow[t]{2}{*}{ Cerebellum } & $\begin{array}{l}\text { DWI Tanpa } \\
\text { PROPELLER }\end{array}$ & 0 \\
\hline & DWI PROPELLER & 4.50 \\
\hline \multirow[t]{2}{*}{$\begin{array}{l}\text { Kelainan Stroke } \\
\text { (batas) }\end{array}$} & $\begin{array}{l}\text { DWI Tanpa } \\
\text { PROPELLER }\end{array}$ & 0 \\
\hline & DWI PROPELLER & 4.50 \\
\hline \multirow[t]{2}{*}{ Artefak } & $\begin{array}{l}\text { DWI Tanpa } \\
\text { PROPELLER }\end{array}$ & 0 \\
\hline & DWI PROPELLER & 4.50 \\
\hline
\end{tabular}
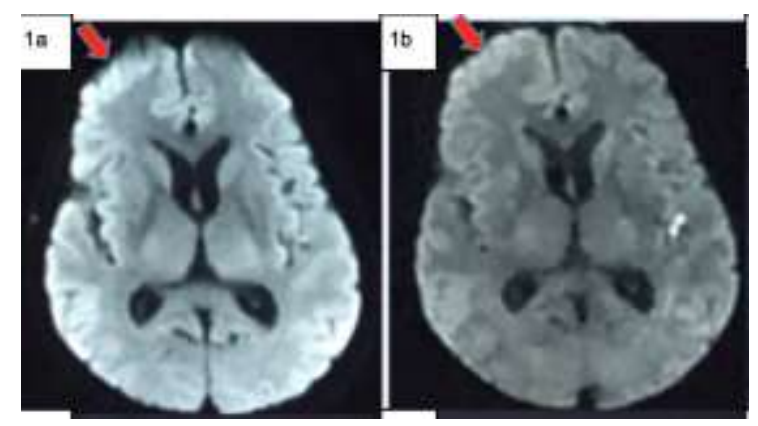

Gambar 2. Citra DWI Tanpa PROPELLER pada Cortex Cerebri (1a), Citra DWI PROPELLER pada Cortex

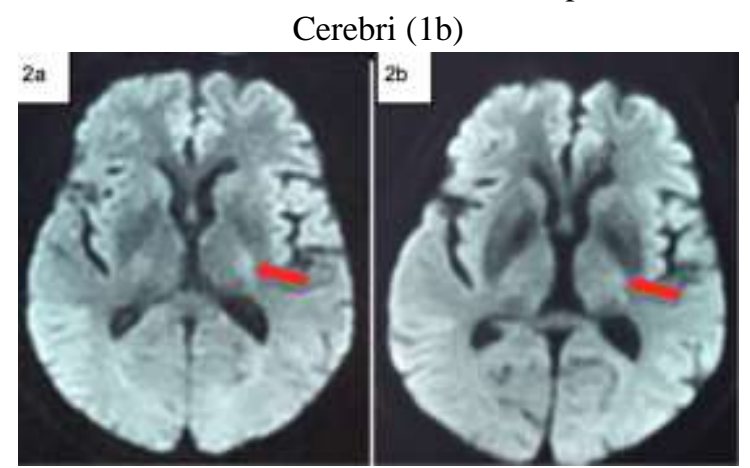

Gambar 3. Citra DWI Tanpa PROPELLER pada Thalamus (2a), Citra DWI PROPELLER pada Thalamus (2b) 

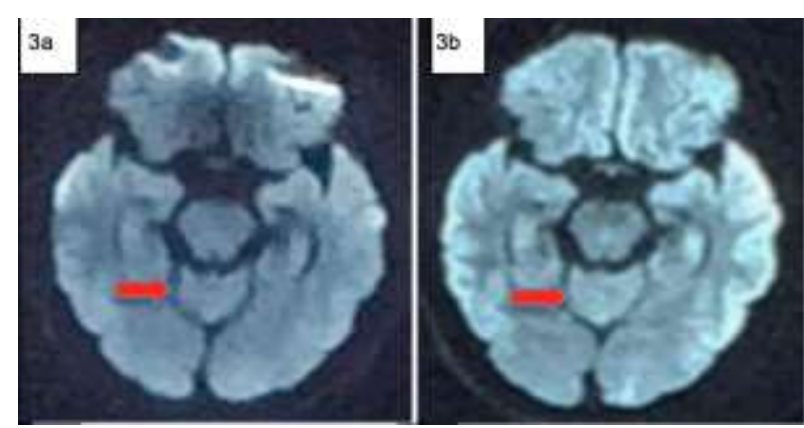

Gambar 4. Citra DWI Tanpa PROPELLER pada Cerebellum (3a), Citra DWI PROPELLER pada Cerebellum (3b)

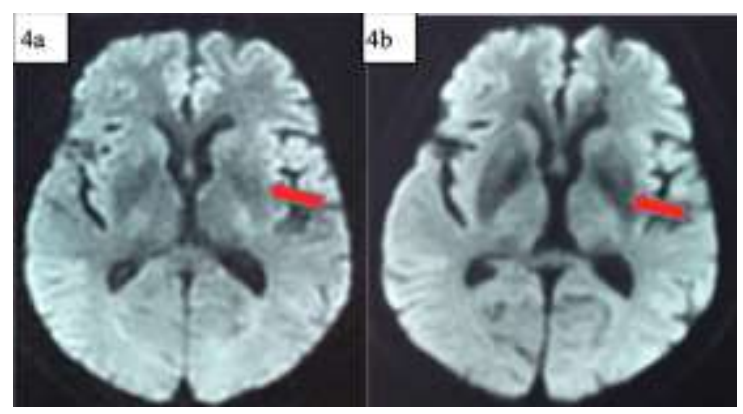

Gambar 5. Citra DWI Tanpa PROPELLER pada Basal Ganglia (4a), Citra DWI PROPELLER pada Basal Ganglia (4b)

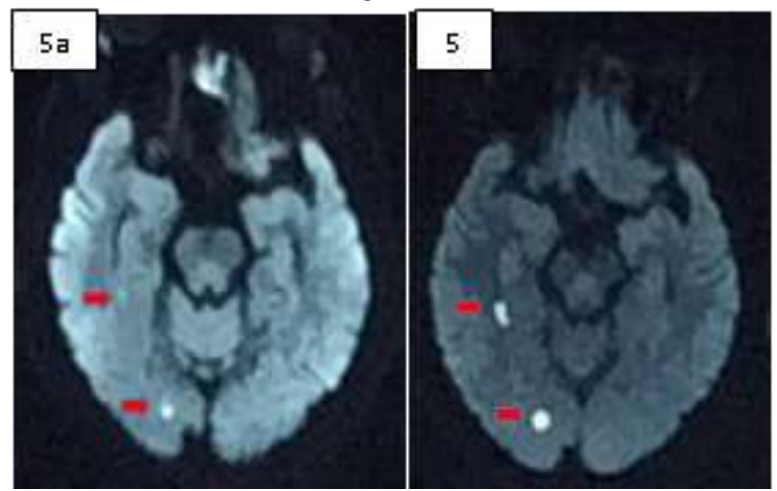

Gambar 6. Citra DWI Tanpa PROPELLER pada Kelainan Stroke(5a), Citra DWI PROPELLER pada kelainan stroke $(5 b)$

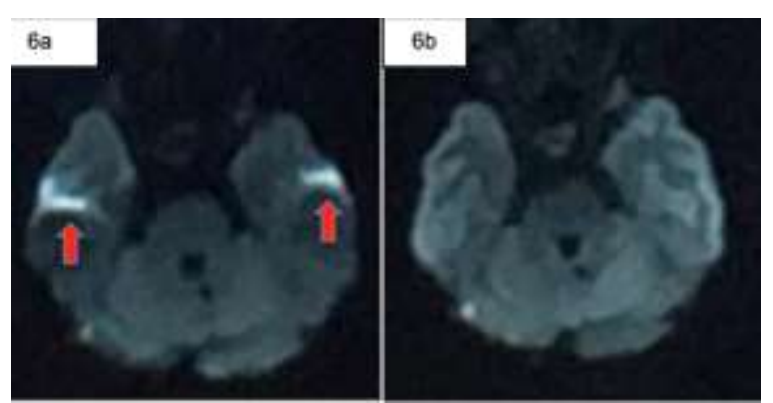

Gambar 7. Citra DWI Tanpa PROPELLER pada artefak (6a), Citra DWI PROPELLER tanpa $\operatorname{artefak}(6 b)$

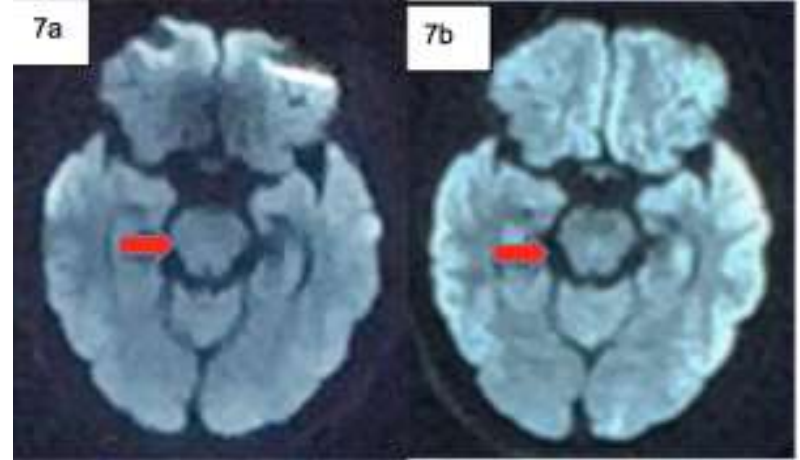

Gambar 8. Citra Dwi Tanpa PROPELLER pada Pons (7a), Citra DWI PROPELLER pada Pons (7b)

Hasil Informasi Citra Anatomi Sekuen Diffusion Weighted Imaging (DWI) antara penggunaan PROPELLER dengan tanpa PROPELLER pada pemeriksaan MRI Brain dengan kasus stroke.

Uji Wilcoxon merupakan uji beda untuk mengetahui ada tidaknya pada setiap variable. Pada Uji Wilcoxon keseluruhan organ pada sekuen DWI dengan dan tanpa PROPELLER yaitu $\mathrm{p}<0.05$ yaitu Ha diterima artinya terdapat perbedaan pada sekuen DWI dengan dan tanpa PROPELLER. Kemudiam dilakukan Uji Wilcoxon pada masing-masing organ anatomi untuk Cortex Cerebri, Basal Ganglia, Thalamus, Pons, Cerebellum, Kelainan Stroke (batas) dan artefak nilai $\mathrm{p}<0.05$ yaitu Ha diterima artinya ada perbedaan informasi citra pada sekuen DWI dengan dan tanpa PROPELLER. Perbedaan tersebut dipengaruhi karena adanya perbedaan pada pengisian $K$ space pada masing-masing sekuen. Menurut Pipe dan Zwart (2006), penggunaan PROPELLER pada DWI dapat meningkatkan resolusi gambar

Hasil penilaian Informasi citra anatomi yang lebih baik pada sekuen Diffusion Weighted Imaging (DWI) antara penggunaan PROPELLER dengan tanpa PROPELLER pada pemeriksaan MRI Brain pada Kasus Stroke

Berdasarkan Hasil Uji Wilcoxon hasil mean rank tertinggi yaitu pada sekuen DWI PROPELLER dengan mean rank 4.50 sedangkan hasil mean rank pada sekuen DWI Tanpa PROPELLER yaitu 0. Dilihat berdasarkan nilai mean rank tersebut untuk gambaran hasil yang paling baik berdasarkan Uji Wilcoxon adalah pada sekuen DWI PROPELLER. 
Sekuen DWI PROPELLER menghasilkan gambaran yang memiliki informasi citra anatomi yang lebih baik bila dibandingkan dengan informasi citra pada sekuen DWI tanpa PROPELLER. Selain hal tersebut, pada sekuen DWI PROPELLER tidak ditemukan adanya artefak susceptibility seperti yang biasanya kita sering jumpai pada sekuen DWI tanpa PROPELLER. Pada sekuen DWI PROPELLER memiliki resolusi yang lebih baik sehingga visualisasi gambaran pada DWI PROPELLER lebih terlihat jelas bila dibandingkan dengan DWI tanpa PROPELLER. Penelitian ini sesuai dengan teori Pipe dan Zwart (2006) yang mengatakan bahwa penggunaan PROPELLER pada DWI dapat meningkatkan resolusi gambar. Teknik dari gambar PROPELLER adalah mengukur frekuensi spasial dalam strip atau blade yang melewati pusat $k$ space dalam proses memperoleh setiap gambar.

Pada sekuen DWI PROPELLER pengisian $k$ space tidak lagi secara rectilinear yang memperoleh data line by line yang digunakan pada sekuen DWI tanpa PROPELLER melainkan pengisian $k$ space secara radial oleh multiple blade (bilah) yang berotasi 360 derajat pada pusat $\mathrm{k}$ space yang di sampling berulang kali dan setiap blade berisi phase encoding lines yang dapat meminimalisir phase eror motion. Hasil penelitian ini juga diperkuat dengan teori Jae-Hwan Cho, dkk (2013) yang mengatakan bahwa pada sekuen DWI Tanpa PROPELLER menggunakan teknik pengambilan data singleshot sedangkan pada sekuen DWI PROPELLER menggunakan teknik pengambilan data multishot, dimana teknik pengambilan data dengan teknik single shot memiliki kekurangan pada low spasial resolution.

Hasil penelitian ini didapatkan bahwa artefak lebih banyak ditemukan pada sekuen DWI tanpa PROPELLER dan pada sekuen DWI PROPELLER tidak ditemukan adanya artefak, hal ini sesuai dengan teori jae hwan cho dkk (2013) yang menyatakan bahwa pada DWI terdapat artefak pada tulang tulang seperti tulang temporal dan frontal. Menurut Elstrad (1993), garam kalsium (seperti ditemukan pada tulang kortikal) adalah zat yang paling kuat medan magnetiknya dalam tubuh manusia dan hampir semua jaringan biologis (otot, lemak, otak, air) juga bersifat diagmanetik namun sangat lemah. Selain itu, adanya artefak pada sekuen DWI menurut William (2009) pada standar SE EPI yang digunakan pada DWI menggunakan teknik single shot, dengan mengunakan single shot ini maka arah fase encoding dibaca dengan satu kali dalam teknik single shot, maka akan meningkatkan sensitivitas scan EPI tersebut terhadap inhomogenitas medan magnet seperti pada tulang. Karena EP DWI menggunakan high gradient magnet field, hal ini menyebabkan sekuen DWI sensitif terhadap medan magnet dan artefak yang menurunkan kualitas gambar.

Pada sekuen DWI PROPELLER pengisian $k$ space menggunakan banyak pulsa 180 yang ditempatkan secara padat dan berulang, oleh karena itu spin kembali rephase meskipun melewati area magnet heterogenitas dan meghasilkan dephase yang rendah. Sehingga dengan penggunaan PROPELLER pada sekuen DWI dapat meningkatkan kualitas gambar dimana pada sekuen DWI PROPELLER lebih jelas menampakan kriteria anatomi dan tidak terdapatnya artefak magnetic susceptibility pada citra.

\section{Simpulan}

Berdasarkan hasil penelitian dan pembahasan dapat disimpulkan bahwa ada perbedaan informasi citra anatomi sekuen Diffussion Weighted Imaging (DWI) antara penggunaan PROPELLER dengan tanpa PROPELLER pada pemeriksaan MRI Brain dengan kasus stroke. dengan nilai signifikansi = $0.00(\mathrm{p}<0.05)$ yang berarti ada perbedaan informasi citra anatomi pada organ cortex cerebri, basal ganglia, thalamus, pons, cerebellum pons, dan kelainan stroke dan nilai signifikansi $0.009(\rho<$ 0.05 ) pada informasi citra artefak yang berarti ada perbedaan informasi citra artefak pada sekuen DWI antara penggunaan PROPELLER dengan tanpa PROPELLER.

Sekuen DWI PROPELLER memiliki informasi citra anatomi yang lebih baik bila dibandingkan dengan sekuen DWI tanpa PROPELLER dalam pemeriksaan MRI Brain dengan kasus stroke dengan nilai mean rank informasi citra anatomi sekuen DWI PROPELLER 4.50 dan mean rank informasi citra anatomi sekuen DWI tanpa PROPELLER 0.00 . 


\section{Daftar Pustaka}

Applegate, E.J. 2010. "The Sectional Anatomy Learning System third Edition",SaundersElsevier,US

Cho, Jae-Hwan. 2013. "A comparative Quantitative Analysis of Magnetic Susceptibility Artifacts in Evho Planar and PROPELLER Diffusion weighted images". Journal of Korean Physical Society; 62:358-364

Dale, B.M., Brown, M.A., Semelka, R.C. 2015. "MRI Basic Principles and Applications Fifth Edition"; John Wiley \& Sons, Ltd; UK

Dewanto, George.2009. Panduan Praktis dan Tatalaksana Penyakit Saraf. Jakarta: EGC

Ellis Harold, 2002, " Clinical Anatomy Tenth Edition", Blackwell, UK

Elster AD. 1993. Sellar susceptibility artifacts: theory and implications. AJNR Am J Neuroradiol; 14:129-136.

Evelyn C, Pearce. 2008. Anatomi dan fisiologi untuk para medis. Jakarta: PT Gramedia.

James G. Pipe, Victoria G. Farthing. 2002. "Multishot Diffusion Weighted FSE Using PROPELLER MRI". Barrow Neurogical Institute, Phoenix, Arizona., Michael G. Aquilia. 1996. Technical Magnetic Resonance Imaging. McGraw Hill Professional

Listiono Djoko,1998, "Ilmu Bedah Syaraf Satyanegaea Edisi III", PT Gramedia Pustaka Utama, Jakarta

Moeller, Torsten B. 2010. "MRI Parameters and Positioning. Thieme

Moritani,T, Ekholm S, Westersson,P.L (2005) " Diffusion Weighted MR Imaging of the Brain",AM-Production, Germany

Nesseth R, 2010, Procedur and documentation for CT and MRI, Mc. Graw- Hili Medical Publishing Division, Kansas

Notosiswoyo M., Suswati, S.; 2004; "Media Litbang Kesehatan, Pemanfaatan Magnetic Resonance Imaging (MRI) Sebagai Sarana Diagnose Pasien", No. 3 Vol XIV.

Noerjanto, M., 2002. Masalah-masalah Dalam Diagnosis Stroke Akut. Management of Acute Stroke. Badan Penerbit Universitas Diponegoro. Semarang.

Nursalam, 2008. Konsep dan Penerapan Metodologi Penelitian Ilmu Keperawatan : Jakarta: Salemba Medika

R, Louise Caplan, 2016, Stroke A Clinical Approach, Fifth Edition, University Printing House, USA.
Sherwood, L., 2009. Fisiologi Manusia dari Sel ke Sistem. Edisi VI. EGC. Jakarta

Sjahriar, Rasad. 2006 Radiologi Diagnostik. 2rd eds. Jaypee Brothers Medical Publishers. New Delhi

Snell,R.S,1997, "Neurologi Klinis Edisi 7", EGC, Jakarta

Sugiyono. 2010. Metode Penelitian Pendidikan Pendekatan Kuantitatif, kualitatif, dan R\&D. Bandung: Alfabeta

Syaifuddin. 2011. Anatomi Fisiologi: Kurikulum Berbasis Kompetensi untuk Keperawatan dan Kebidanan Edisi 4. Jakarta: EGC.

Westbrook C \& Kaut C, 1998; "MRI in Practice, 2nd"; Blackwell Science, Oxford

Westbrook C., Roth, C.K., and Talbot J.; 2011, "MRI in Practice, 4th Edition", Blackwell Science Ltd, UK

Westbrook C., Roth, C.K.; 2014, "Handbook of MRI Technique 4th Edition", Blackwell Science Ltd, UK

Victor, M. 2001. Principle of Neurology, Seventh edition. Mc Graw Hill Book Company, New York.

Pipe JG. 1999. Motion correction with PROPELLER MRI: application to head motion and free-breathing cardiac imaging. Magn Reson Med

Potter, Perry. (2010). Fundamental Of Nursing: Consep, Proses and Practice. Edisi 7. Vol. 3. Jakarta : EGC

Ulrike I. Attenberger. 2009. A Comprehensive Evaluation of a Fast Spin Echo DWI Sequence With BLADE (PROPELLER) kSpace Sampling at $3 \mathrm{~T}$, Using a 32-Channel Head Coil in Acute Brain Ischemia.Invest radiol44: 656-661) 